\title{
PENELITIAN
}

\section{PERBEDAAN PENGELUARAN ASI PERTAMA ANTARA PIJAT OKSITOSIN DAN BREAST CARE PADA IBU NIFAS DI WILAYAH NATAR LAMPUNG SELATAN}

\author{
Yusari Asih*, I Gusti Ayu Mirah WS*, Tiya Setiawati* \\ Jurusan Kebidanan Poltekkes Tanjungkarang \\ E-mail: yusariasih@ @mail.com
}

\begin{abstract}
Berdasarkan data cakupan pemberian Asi ekslusif di Provinsi Lampung masih rendah (54,9\%) dibandingkan dengan target Indonesia. Berdasarkan data di puskesmas wilayah natar cakupan pemberian ASI hanya $62,3 \%$, hasil ini dibawah target yaitu sebesar $80 \%$. Hasil survei di wilayah Natar terdapat 8 ibu dari 40 ibu post partum yang tidak memberikan ASI kepada bayinya, 3 diantaranya karena putting susu tidak keluar, 5 diantaranya tidak memberikan ASI dikarenakan ASI sedikit dan memberikan PASI sebagai gantinya. Masalah dalam penelitian ini adalah rendahnya cakupan pemberian ASI. Penelitian ini merupakan penelitian eksperimental dengan rancangan eksperimen menggunakan Quasy Eksperimen dengan pendekatan posttest Only Control Group Design dilakukan pada tahun 2018, populasi dalam penelitian ini adalah seluruh ibu post partum normal di BPM Siti Hajar. Teknik sampel penelitian ini menggunakan purposive sampling. Data yang diambil adalah data primer alat yang digunakan berupa ceklist dan lembar observasi. Analisis data yang digunakan adalah analisis univariat dengan rerata dan bivariat dengan Mann-Whitney. Hasil uji statistik dapat disimpulkan terdapat perbedaan signifikan pengeluaran ASI antara Pijat Oksitosin dan Breast Care dengan $p$ value 0,002. Diharapkan petugas kesehatan mengajarkan pijat oksitosin agar dapat memperlancar pengeluaran ASI.
\end{abstract}

Kata kunci: Pengeluaran ASI, Pijat Oksitosin, Breastcare

\section{LATAR BELAKANG}

Air susu ibu (ASI) merupakan makanan ideal untuk bayi. ASI mengandung gizi tinggi yang sangat bermanfaat untuk kesehatan bayi, bahkan Badan Kesehatan Dunia (WHO) merekomendasikan bayi untuk mendapatkan ASI ekslusif selama enam bulan. Namun ternyata, capaian ASI ekslusif di Indonesia belum mencapai angka yang diharapkan.

Data Badan Kesehatan Dunia (WHO) tahun 2016 masih menunjukkan rata-rata angka pemberian ASI ekslusif di dunia baru berkisar 38 persen. Di Indonesia meskipun sejumlah besar perempuan (96\%) menyusui anak mereka dalam kehidupan mereka, hanya $42 \%$ dari bayi yang berusia dibawah 6 bulan yang mendapatkan ASI ekslusif.

Jika dibandingkan dengan target WHO yang mencapai 50\%, maka angka tersebut masih jauh dari target. Berdasarkan data yang dikumpulkan International Baby Food
Action Network (IBFAN) 2014, Indonesia menduduki peringkat ke tiga terbawah dari 51 negara di dunia yang mengikuti penilaian status kebijakan dan program pemberian makanan bayi dan anak (Infant- Young Child feeding).

Proses mulai menyusui terjadi pada 1 6 jam setelah kelahiran 35,2\% dan kurang dari 1 jam ( inisiasi menyusui dini) sebesar $34,5 \%$, sedangkan proses mulai menyusui terendah terjadi pada 7-23 jam setelah kelahiran yaitu sebesar 3,7\% (Profil Kesehatan Indonesia, 2015). Berdasarkan data Ditjen Kesehatan Masyarakat, Kemenkes RI, 2016 cakupan pemberian ASI ekslusif pada bayi umur 0-6 bulan di Indonesia 55,7\%, sedangkan pada Provinsi Lampung yaitu 54,9\% (Profil Kesehatan Indonesia 2016). Berdasarkan data di atas diketahui bahwa Lampung mempunyai cakupan ASI yang cukup rendah dibandingkan dengan target Indonesia. 
Berdasarkan data dari seluruh puskesmas di wilayah Kabupaten Lampung Selatan tahun 2014 cakupan pemberian ASI ekslusif untuk bayi 0-6 bulan mencapai $(71,6 \%)$. Hasil ini dibawah target yaitu sebesar $80 \%$, dan di wilayah natar cakupan pemberian ASI hanya 62,3\%. Jika dilihat dari data diatas wilayah Natar belum mencukupi target cakupan ASI Kabupaten Lampung Selatan.

Dampak yang dapat ditimbulkan dari rendanya cakupan pemberian ASI secara ekslusif ini dapat berdampak pada kualitas hidup generasi penerus bangsa dan juga pada perekonomian nasional. Rendahnya cakupan pemberian ASI disebabkan oleh banyak faktor yang mempengaruhi produksi dan pengeluaran ASI tersebut salah satunya yaitu disebabkan karna kurangnya pengetahuan Intervensi/ teknik yang dapat merangsang pengeluaran ASI yaitu teknik breast care dan pijat oksitosin.

Upaya atau rangsangan untuk meningkatkan produksi dan pengeluaran ASI yang banyak di lakukan di BPM baru breast care, itupun hanya dilakukan di klinik. Ketika pasien sudah pulang biasanya tidak dilakukan karena kendala kurangnya pengetahuan dari keluarga. Sementara ada metode baru yaitu pijat oksitosin yang dapat dilakukan oleh keluarga terutama suami karna selain dapat meningkatkan hormon oksitosin juga memberikan kenyamanan bagi ibu pada saat menyusui. Diharapkan dengan melakukan intervensi yaitu pijat oksitosin dan breast care dapat membantu cakupan pemberian ASI agar sesuai dengan target yang diharapkan.

Berdasarkan hasil wawancara pada bulan Oktober 2017 terdapat 8 ibu dari 40 ibu post partum yang tidak memberikan ASI kepada bayinya, 3 diantaranya karena putting susu tidak keluar, 5 diantaranya tidak memberikan ASI dikarenakan ASI sedikit dan memberikan PASI sebagai gantinya.

\section{METODE}

Jenis penelitian kuantitatif, penelitian dilakukan di wilayah Natar Lampung Selatan selama satu bulan yaitu pada Maret-April 2018. Rancangan penelitian quasy eksperimen dengan pendekatan one group post test only design. Populasi dalam penelitian ini adalah seluruh ibu nifas di salah satu BPM wilayah Natar Lampung Selatan, sejumlah 32 orang.

Sampel pada penelitian ini sebanyak 16 orang ibu nifas Jumlah sampel ditambah $10 \%$ sebesar 1,6=2 untuk kemungkinan drop out. Jadi sampel yang dilakukan pijat oksitosin 18 ibu nifas dan 18 orang ibu nifas diberikan breast care, sehingga sampel yang digunakan adalah 36 ibu post partum.

Variabel dependen dalam penelitian ini adalah pengeluaran ASI pertama.Variabel independen dalam penelitian ini adalah pijat oksitosin dan breast care. Analisis univariat dilakukan dengan analisis distribusi frekuensi dan hasil statistik deskriptif dari variabel yang diteliti meliputi mean, median, standart deviasi, nilai minimal dan maksimal. Analisa bivariat dilakukan untuk melihat perbedaan pengeluaran asi pertama antara pijat oksitosin dan breast care pada ibu nifas, analisis bivariat dilakukan dengan cara Uji Mann-Witney.

\section{HASIL}

\section{Analisis Univariat}

Tabel 1: Distribusi Responden Berdasarkan Pengeluaran ASI Menggunakan Pijat Oksitosin

\begin{tabular}{lcc}
\hline \multicolumn{1}{c}{ Pengeluaran ASI } & f & $\%$ \\
\hline 2 hari & 3 & 18,75 \\
\hline 3 hari & 10 & 62,5 \\
\hline 4 hari & 3 & 18,75 \\
\hline Jumlah & 16 & 100 \\
\hline
\end{tabular}


Berdasarkan Tabel di atas diperoleh hasil dari 16 responden yang diberikan teknik pijat Oksitosin pengeluaran ASI 2 hari 3 responden,pengeluaran ASI 3 hari 10 responden,pengeluaran ASI 4 hari 3 responden.

Tabel 2: Distribusi Rerata Pengeluaran ASI Pertama dengan Menggunakan Teknik Pijat Oksitosin

\begin{tabular}{lcccc}
\hline Variabel & Mean & SD & Min-Maks & $95 \%$ CI \\
\hline $\begin{array}{l}\text { Pijat } \\
\text { Oksitosin }\end{array}$ & 3 & 0,632 & $2-4$ & $2.663-3.337$ \\
\hline
\end{tabular}

Berdasarkan tabel di atas didapatkan rata-rata pengeluaran ASI pertama dengan menggunakan teknik Pijat Oksitosin adalah 3 hari (95\% CI: 2.6630- 3.3370), dengan standar deviasi 0,632 hari. Pengeluaran ASI tercepat yaitu 2 hari dan terlambat 4 hari. Dapat disimpulkan bahwa 95\% diyakini bahwa rata-rata pengeluaran ASI adalah diantara 2.6630 sampai dengan 3.3370 hari.

Tabel 3: Distribusi Responden Berdasarkan Pengeluaran ASI Menggunakan Breast Care

\begin{tabular}{lcc}
\hline \multicolumn{1}{c}{ Pengeluaran ASI } & $\mathrm{f}$ & $\%$ \\
\hline 2 hari & 4 & 25 \\
\hline 3 hari & 11 & 68,75 \\
\hline 4 hari & 1 & 6,25 \\
\hline Jumlah & 16 & 100 \\
\hline
\end{tabular}

Berdasarkan tabel di atas diperoleh hasil dari 16 responden yang diberikan teknik breast care pengeluaran ASI 3 hari 4 responden,pengeluaran ASI 4 hari 11 responden,pengeluaran ASI 5 hari 1 responden.

Tabel 4: Distribusi Rerata pengeluaran ASI pertama dengan menggunakan teknik Breast Care

\begin{tabular}{lcccc}
\hline Variabel & Mean & SD & Min-Maks & $95 \%$ CI \\
\hline $\begin{array}{l}\text { Breast } \\
\text { Care }\end{array}$ & 3.8 & 0.543 & $3-5$ & $3.5227-4.1023$ \\
\hline
\end{tabular}

Berdasarkan tabel di atas dapat diketahui bahwa rata-rata pengeluaran ASI pertama dengan menggunakan teknik breast care adalah 3.8 hari (95\% CI: 3.52274.1023), dengan standar deviasi 0.543 hari. Pengeluaran ASI tercepat 3 hari dan terlamabat 5 hari. Disimpulkan bahwa 95\% diyakini bahwa rata-rata pengeluaran ASI adalah diantara 3.5227 sampai dengan 4.1023 hari

\section{Analisis Bivariat}

Normalitas data diuji dengan menggunakan Test of Normality SaphiroWilk. Hasil uji normalitas data menunjukan bahwa data pengeluaran asi pertama kelompok pijat oksitosin dan breast care memiliki nilai kemaknaan 0.002. Data kedua kelompok memiliki nilai kemaknaan (p) $<0,05$ sehingga dapat disimpulkan bahwa data tidak berdistribusi dengan normal. Data yang diperoleh dari kedua kelompok berdistribusi tidak normal sehingga uji hipotesis yang dilakukan adalah uji komparatif dua kelompok tidak berpasangan yaitu uji Mann-Whitney.

Tabel 5: Hasil Uji Hipotesis Mann-Whitney Data

Pengeluaran Asi Pertama Antara Pijat oksitosin dan Breast Care

Test Statistik

\begin{tabular}{ll}
\hline & \multicolumn{1}{c}{ Nilai } \\
\hline Mann- Whitney U & 48.500 \\
Wilkoxon W & 184.500 \\
Z & -3.284 \\
Asymp. Sig. (2-tailed) & 0.001 \\
Exact Sig.2 (1- tailed Sig) & 0.002 \\
\hline
\end{tabular}

Tabel di atasi menunjukkan hasil uji hipotesis dengan Mann- Whitney diperoleh nilai signifikansi 0.02 . Nilai signifikansi (p) $<0,005$ sehingga dapat disimpulkan bahwa ada perbedaan yang signifikan antara pengeluaran ASI dengan teknik pijat oksitosin dan breast care pada ibu Nifas. 


\section{PEMBAHASAN}

Rerata pengeluaran ASI pertama dengan menggunakan teknik pijat oksitosin pada ibu nifas di BPM Natar Lampung Selatan Tahun 2018. Hasil analisis diketahui bahwa pengeluaran ASI pertama responden di BPM Kecamatan Natar Lampung Selatan tahun 2018 berbeda-beda. Berdasarkan tabel 4.2 didapatkan nilai rerata pengeluaran ASI pertama pada responden yang diberikan intervensi pijat oksitosin yaitu 3 hari.

Hal ini sesuai dengan pendapat (Biancuzzo, 2003: Indiyani 2006, Yohmi \& Roeslli, 2009) pijatan oksitosin ini berfungsi untuk meningkatkan hormon oksitosin yang dapat menenangkan ibu, sehingga ASI otomatis keluar, sedangkan menurut (Bobak, 2005) Pengeluaran ASI ini terjadi karena sel otot halus di sekitar alveoli mengerut sehingga memeras ASI untuk keluar. penyebab otot-otot ini mengerut adalah suatu hormon yang dinamakan oksitosin.

Berdasarkan uraian di atas, maka menurut peneliti pijat oksitosin merupakan salah satu cara yang efektif untuk membantu proses pengeluaran ASI, dikarenakan pijatan yang dilakukan pada sepanjang tulang belakang dapat menekan titik-titik pengeluaran ASI pada punggung yang sejajar dengan payudara sehingga dapat merangsang hormone oksitosin atau reflek pengeluaran ASI.

Maka dari itu penting bagi tenaga kesehatan untuk memberikan informasi terbaru dan mengajarkan cara melakukan pijat oksitosin kepada keluarga dengan baik dan benar sehingga dapat bermanfaat bagi ibu dan bayi.

Hasil analisis diketahui bahwa pengeluaran ASI pertama responden di BPM Kecamatan Natar Lampung Selatan tahun 2018 berbeda-beda. Berdasarkan hasil didapatkan nilai rerata pengeluaran ASI pertama pada responden yang diberikan intervensi breast care yaitu 3.8125 atau 3,8 hari.

Menurut (Bahiyatun, 2009) breast care merupakan salah satu usaha untuk memperbanyak ASI dengan melakukan pemijatan atau masase untukmemberikan rangsangan pada otot-otot payudara/ kelenjarar ASI untuk memproduksi ASI.

Perawatan payudara (breast care) adalah suatu cara merawat payudara yang dilakukan pada saat kehamilan atau masa nifas untuk produksi ASI, selain itu untuk kebersihan payudara dan bentuk putting susu yang masukke dalam atau datar. Putting susu demikian sebenarnya bukanlah halangan bagi ibu untuk menyusui dengan baik dengan mengetahui sejak awal, ibu mempunyai untuk mengusahakan agar putting susu lebih mudah sewaktu menyusui,disamping itu juga sangat penting memperhatikan kebersihan personal hygine (Rustam, 2007).

Berdasarkan uraian tersebut di atas, maka menurut peneliti breast care adalah cara yang tepat untuk membantu agar pengeluaran ASI tidak terganggu yaitu dengan cara mencegah payudara tersumbat. Pengurutan pada bagian payudara dapat merangsang kelenjar air susu sehingga produksi ASI lancar.

Maka dari itu penting bagi bidan agar dapat memberikan informasi tentang breast care lebih awal yaitu pada masa kehamilan agar ibu dapat menjaga personal hygine dan memperbaiki bentuk putting yang bermasalah.

Hasil penelitian juga mengetahui adanya perbedaan pengeluaran ASI petama antara pijat oksitosin dan breast care pada ibu nifas. Hasil analisis uji hipotesis dengan uji mann-Whitney diketahui nilai $\mathrm{p}=0,002$ yang artinya ada perbedaan antara pijat oksitosin dan breast care terhadap pengeluaran ASI pada ibu nifas di BPM Kecamatan Natar Lampung Selatan.

Pijat oksitosin dapat menstimulasi pelepasan hormon oksitosin dari kelenjar hipofisis posterior, yaitu pemijatan sepanjang tulang belakang (vertebra) sampai costae kelima atau keenam. Melalui pijatan atau rangsangan pada tulang belakang, neurotransmiter akan merangsang medulla oblongata langsung mengirim pesan ke 
hipotalamus di hipofisis posterior untuk mengeluarkan oksitosin akan meningkatkan pengeluaran ASI (Suryani dkk, 2013 )

Berbeda halnya dengan breast care, bertujuan untuk melancarkan sirkulsi darah dan mencegah tersumbatnya saluran susu sehingga memperlancar pengeluaran ASI, serta menghindari terjadinya pembengkakan dan kesulitan menyusui, selain itu juga menjaga kebersihan payudara agar tidak mudah terinfeksi (Kristiyanasari, 2009).

Berdasarkan uraian tersebut di atas, maka menurut peneliti pengeluaran ASI pertama dipengaruhi oleh beberapa faktor salah satunya rangsangan dari luar yang dapat membuat proses pengeluaran ASI menjadi lebih cepat, rangsangan dari luar yang dapat dilakukan oleh ibu adalah breast care selain itu ada metode baru yang dapat membuat pengeluaran ASI menjadi lebih cepat yaitu pijat oksitosin.

Maka dari itu penting pula bagi tenaga kesehatan terutama bidan untuk dapat menyampaikan informasi baru kepada ibu hamil, agar sebelum mereka melahirkan mereka dapat mengetahui bagaimana agar pengeluran ASI mereka normal dan memberikan kesiapan kepada ibu untuk proses menyusui nantinya. dan diharapkan bidan dapat mengajarkan pijat oksitosin ini kepada keluarga atau kepada ibu nifas agar pijat oksitosin ini dapat dilakukan dengan segera setelah proses persalinan sehingga dapat membuat ibu yang telah bersalin menjadi rileks dan merasakan mendapat perhatian khusu dari pihak keluarga melalui pijatan yang diberikan dan hal ini dapat membuat ASI ibu lebih cepat keluar.

\section{KESIMPULAN}

Hasil penelitian menyimpulkan bahwa dari 16 responden yang diberikan teknik pijat oksitosin pengeluaran ASI pertama selama 2 hari 3 responden, selama 3 hari 10 responden,selama 4 hari 3 responden. Rerata pengeluaran ASI pertama pada ibu nifas yang diberikan teknik pijat oksitosin adalah ( 3 hari). Sedangkan dari 16 responden yang diberikan Breast Care pengeluaran ASI pertama selama 3 hari 4 responden,selama 4 hari 11 responden,selama 5 hari 1 responden Rerata pengeluaran ASI pertama pada ibu nifas yang diberikan teknik Breast Care adalah ( 3,8 hari ).

Selanjutnya penelitian juga menyimpulkan adanya perbedaaan pengeluaran ASI pertama antara pijat oksitosin dan breast care tehadap ibu nifas.

\section{DAFTAR PUSTAKA}

Bahiyatun. (2009). Buku Ajar Asuhan Kebidanan Nifas Normal. Jakata: EGC Bobak, dkk. (2005). Buku Ajar Asuhan Keperawatan Maternitas Edisi 4. Jakarta : EGC

Kristiyanasari, W. (2009). ASI, Menyusui dan Sadari.Yogjakarta : NuhaMedika

Roesli, Utami. (2004). Mengenal ASI Ekslusif. Jakarta : PT Pustaka pembangunan Swadaya Nusantara.

Rustam, M. (2007). Sinopsis Obstetri. Jakarta : EGC

Suryani \& Astuti. (2014). Pengaruh Pijat Oksitosin terhadap Produksi ASI Ibu Post Partum di BPM Wilayah Kabupaten Klaten. Jurnal Terpadu Ilmu Kesehatan. 41-155. 